\title{
$\begin{array}{llllll}\text { FEBRUARY } & 1 & 9 & 9 & 8\end{array}$
}

GRIZZLY SUBSTATION FIBER OPTICS.

ENVIRONMENTAL ASSESSMENT

\section{DOE/BP- 3045}

AEC RUED

APR 13998

OSTI

DISTAIBUTION OF THIS DOCUMENT IS UNLIMTES i⿱ 


\section{DEPARTMENT OF ENERGY \\ Bonneville Power Administration}

Grizzly Substation Fiber Optic Project

Finding of No Significant Impacts (FONSI)

Summary: This notice announces BPA's decision to construct, operate, and maintain the Grizzly Substation Fiber Optic Project (Project). This Project is part of a continuing effort by BPA to complete a regionwide upgrade-of its existing telecommunications system. The U. S. Forest Service and BPA jointly prepared the Grizzly Substation Fiber Optic Project Environmental Assessment (EA) (DOE/EA-1241) evaluating the potential environmental impacts of the Proposed Action, the Underground Installation Alternative, and the No Action Alternative. Based on the analysis in the EA, the U. S. Forest Service and BPA have determined that the Proposed Action is not a major Federal action significantly affecting the quality of the human environment, within the meaning of the National Environmental Policy Act (NEPA) of 1969. Therefore, the preparation of an Environmental Impact Statement (EIS) is not required and BPA is issuing this FONSI. The U. S. Forest Service has separately issued a FONSI and Decision Notice authorizing BPA to construct, operate, and maintain the Project within the Crooked River National Grassland (Grassland).

Address: For copies of this. FONSI, please call BPA's toll-free document request line: $800-622-4520$.

Public Availability: This FONSI will be distributed to all persons and agencies known to be interested in or affected by the Proposed Action or alternatives.

For Further Information, Contact Kathy Fisher - ECN, Bonneville Power Administration, P.O. Box 3621, Portland, Oregon, 97208-3621, phone number 503-230-4375, fax number 503-230-5699.

Supplementary Information: The BPA provides.electricity throughout the Pacific Northwest using a large network of transmission lines, substations, and control centers. The communication system is an essential component to the operation and control of this transmission network. Today, most of BPA's communication system consists of 1960s-era microwave radio technology. Upgrading this communication system with newer technology, such as fiber optics, offers BPA an opportunity to improve transmission system reliability and accommodate future growth.

BPA started a system-wide upgrade of its communication system from microwave to fiber optics in 1994. By adding the Grizzly Substation to the fiber optic network, BPA will upgrade the communications for electric power operations in central Oregon. 
Proposed Action and Alternatives: The Project, described as the Proposed Action in the EA, will involve the construction, operation, and maintenance of a fiber optic communications transmission line. The Project will be approximately $40 \mathrm{~km}$ (25 miles) long and located in Jefferson County, Oregon. All but $8 \mathrm{~km}$ (5 . miles) of the Project will be contained within the boundaries of the Grassland.

The first $32 \mathrm{~km}$ ( 20 miles) of the Project will be installed within existing BPA transmission corridors. The last $8 \mathrm{~km}$ (5 miles) of the Project will be constructed on new easement granted to BPA by the Grassland District Ranger. The Project will involve installing fiber optic cable on new and existing towers along BPA's Celilo - Sylmar and John Day - Grizzly No. 1 transmission lines into the Grizzly Substation. Telecommunications equipment will be installed on racks in the Grizzly Substation control house in the substation yard.

Based on the analysis in the EA, the U. S. Forest Service has granted BPA a 15 meter (50 foot) wide easement that parallels existing county roads. The easement starts at the Grizzly Substation and ends near tower 83/1 of BPA's Big Eddy - Redmond No. 1 transmission line. BPA will install approximately 27 wood poles and attach fiber optic cable to them in this new easement. No new roads will be constructed. However, construction and maintenance vehicles will drive on the natural terrain within the new easement.

Two alternatives to the Proposed Action; the Underground Installation Alternative and the No Action.Alternative were also analyzed in the EA. The Underground Installation Alternative is the same as the Proposed Action, except that the fiber optic cable would be buried underground rather than installed on new poles in the new easement. The Underground Installation Alternative would minimize potential visual impacts along the new easement. However; the U.S. Forest Service and BPA did not choose this alternative because of (1) low visual sensitivity of the area, (2) the greater level of ground disturbance that would result from the trenching needed to bury the cable, and (3) the increased costs needed to bury and maintain underground cable.

Under the No Action Alternative, BPA would not add the Grizzly Substation to the fiber optic network. BPA would continue to use the existing communications system and electric power operations for central Oregon could become . unreliable. Under certain conditions, the unreliability could cause a telecommunications interruption or system failure. This alternative would not have met BPA's need to upgrade the communications system in central Oregon.

Environmental Impacts: Some environmental impacts will occur as a result of the Project, but the impacts will not be significant. Soil disturbance and compaction will be minimal because construction activities will mostly occur on previously disturbed areas. To further reduce erosion potential and loss of soil productivity, construction activities will be avoided when the soil is saturated.

Land Use and Recreation impacts will not be significant because most of the Project will occur within existing utility corridors. Grazing disruptions along the 
new easement will be minimal because of the short construction period. Fencelines inadvertently damaged by project activities will be repaired . immediately by BPA or its construction contractor. Noise and visual impacts to dispersed recreational activities such as hiking and hunting will be temporary and localized.

Most of the Project activities will occur within areas where vegetation has already been disturbed. Continuing maintenance activities along the existing transmission corridors include vegetation management, occasional vehicular travel, and helicopter flyovers. The new poles placed in the existing transmission corridors will be generally located next to existing towers and will remove only a small amount of vegetation.

Some vegetation disturbance will occur during construction and maintenance activities. Potential noxious weed infestations of these disturbed areas will be eliminated because BPA or its contractor will (1) revegetate disturbed areas with certified weed free seed; (2) clean vehicles when moving to new areas, and (3) monitor for new weed infestations after Project completion.

Some juniper trees on the new easement will be removed to allow adequate clearance for the poles and cable. However, because Project design criteria was . included to minimize tree removal, poles will be placed so that many of the juniper trees along the new easement will remain.

Wildlife disturbance during construction and maintenance will be minor because of the temporary nature of those activities: Since the Project will be located either along previously developed facilities or along existing county roads, wildlife habitat loss will be minimal.

The biological evaluation completed by the U. S. Forest Service determined that no federally or state protected plants, animals, or their habitats will be adversely. impacted by the Project. This is also true for fish, wildlife, and plant species identified as sensitive by the Regional Forester.

- No impacts to floodplains or wetlands will result from the Project. Existing transmission structures are located in uplands and existing roads will be used to access the tower sites. A small wetland located on the new easement near Highway 26 will be spanned and avoided.

The Project will have no effect on historical and cultural resources because the only known site along the project area will be avoided by construction activities.

No discernible visual impacts will occur on the section of the Project that is within existing transmission corridors because the visual impact has already been imposed on the landscape. Visual impacts that occur along the new easement will be adverse, but not significant. The Project will parallel existing roads and a local utility corridor and will not be visible from any scenic.highways or sensitive viewing points. The wood poles and dark colored fiber casing used on the new easement will be difficult to discern against the natural landscape. 
Air quality impacts from the Project, primarily from vehicle exhaust and increased fugitive dust, will be short-term and will not exceed any air quality standards.

Site clearing will be minimized and dust abatement measures will be applied to reduce dust generation.

Construction related noise impacts will be short-term and will not result in any serious disturbances to residences.

Because the Project will not produce any electric or magnetic fields, or hazardous or toxic materials, no impacts to public health and safety will occur.

All mitigation measures specifically designed for the Project and described in the EA are adopted and will be monitored.

Determination: Based on the information in the EA, as summarized here; BPA determines that the Proposed Action is not a major Federal action significantly affecting the quality of the human environment within the meaning of NEPA, 42 U.S.C. 4321 et seq. Therefore, an EIS will not be prepared and BPA is issuing this FONSI.

Issued in Portland, Oregon, on February 19, 1998.

\section{Alefmilin B. frith}

Alexandrá B. Smith

Vice President

Environment, Fish and Wildlife Group 


\section{DISCLAIMER}

This report was prepared as an account of work sponsored by an agency of the United States Government. Neither the United Stales Government nor any agency thereof, nor any of their employees, makes any warranty, express or implied, or assumes any legal liability or responsibility for the aceuracy, completeness, or usefulness of any information, apparatus, product, or process disciosed, or represents that its use would not infringe privately owned rights. Reference herein to any specific commercial produce, process, or service by trade name, trademurte, manufacturet, or atherwise does not necessarily constivute or imply its endorsement, recommendation, or favoring by the United States Governmeat or any agency thereof. The views and opinions of authors expressed herein do not necessarily state or reflect those of the United States Government or any agency thereof. 


\section{DISCLAIMER}

Portions of this document may be illegible electronic image products. Images are produced from the best available original document. 


\section{Table of Contents}

\section{TABLE OF CONTENTS}

\section{CHAPTER I - PURPOSE OF AND NEED FOR ACTION}

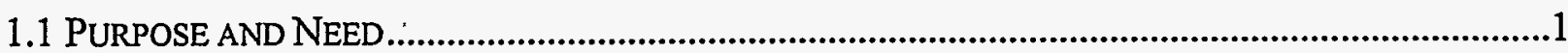

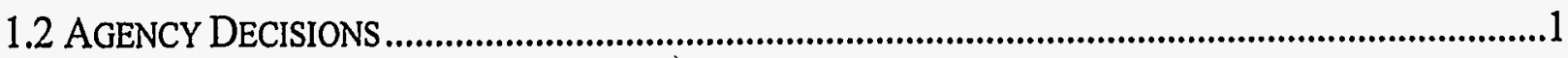

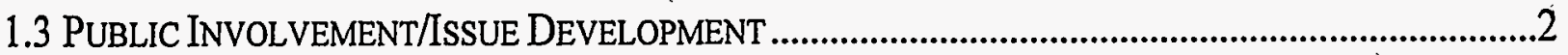

\section{CHAPTER II - ALTERNATIVES INCLUDING THE PROPOSED ACTION}

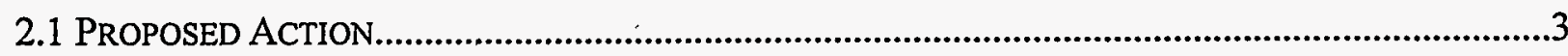

2.1.1 Project Location...........................................................................................................

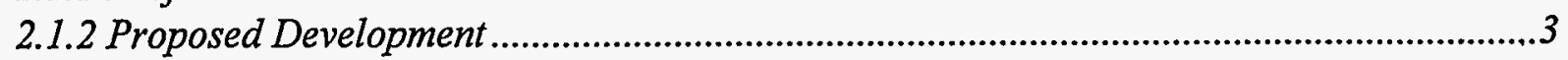

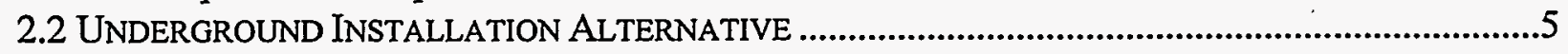

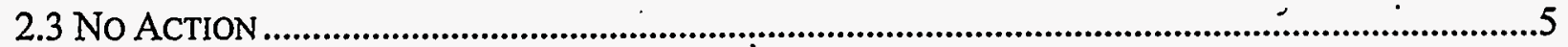

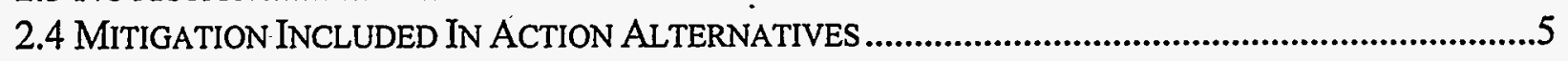

2.5 ALTERNATIVES CONSIDERED BUT ELIMINATED FROM DETAILED STUDY.......................................6

2.5.1 Using Existing Transmission Lines................................................................................6

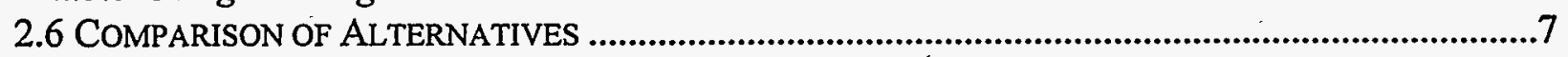

CHAPTER III - AFFECTED ENVIRONMENT, ENVIRONMENTAL CONSEQUENCES, AND MITIGATION MEASURES

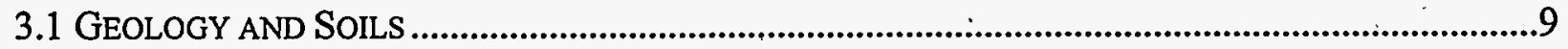

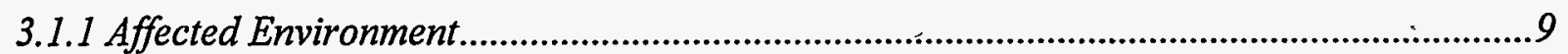

. 3.1.2 Environmental Consequences..............................................................................................

3.2 LAND USE \& RECREATION ....................................................................................................10

3.2.1 Affected Environment ................................................................................................10

3.2.2 Environmental Consequences................................................................................

3.3 BOTANICAL RESOURCES ................................................................................................12

3.3.1 Affected Environment ...............................................................................................12

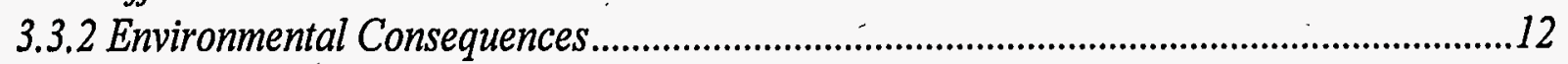

3.4 WILDLIFE (INCLUDING FISHERIES) .....................................................................................13

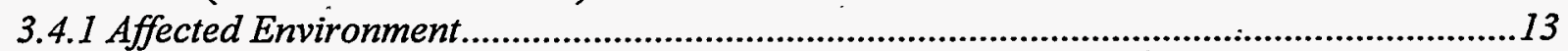

3.4.2 Environmental Consequences................................................................................13

3.5 PRoposed, ENDANGERED, THREATENED, AND SENSITIVE SPECIES ............................................14

3.5.1 Affected Environment ...............................................................................................14

3.5.2 Environmental Consequences.........................................................................................16

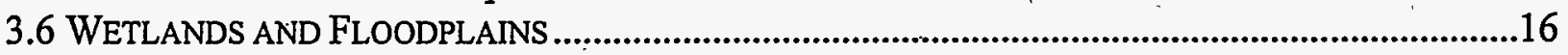

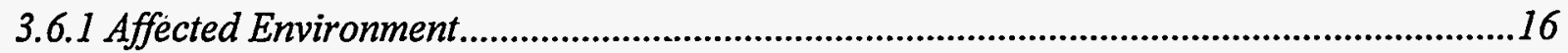

3.6.2 Environmental Consequences.....................................................................................17

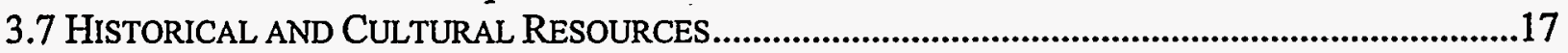

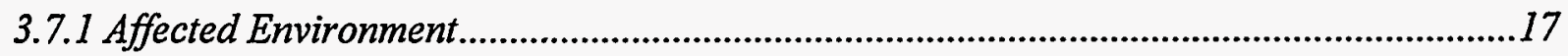

3.7.2 Environmental Consequences.......................................................................................17 


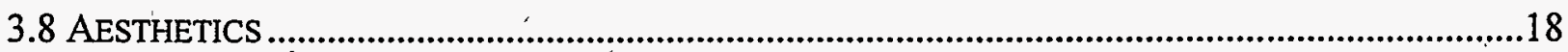

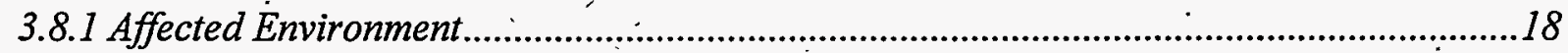

3.8.2 Environmental Consequences ..................................................................................18

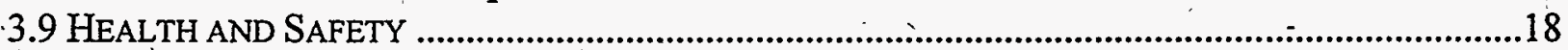

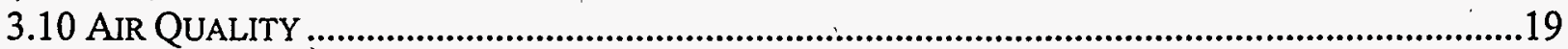

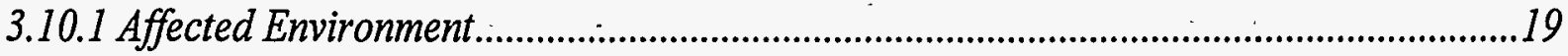

3.10.2 Environmental Consequences...............................................................................19

3.11 NoISE................................................................................................................................

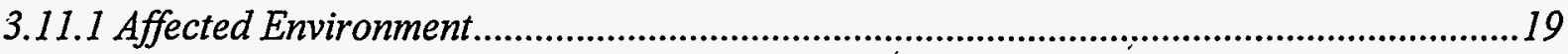

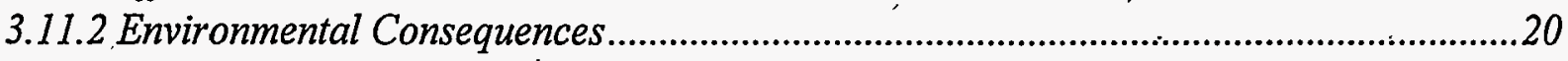

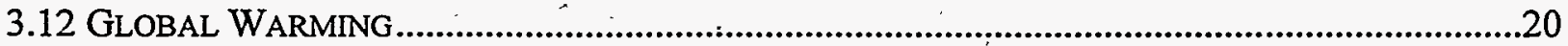

CHAPTER IV - ENVIRONMENTAL CONSULTATION, REVIEW AND PERMIT REQUIREMENTS

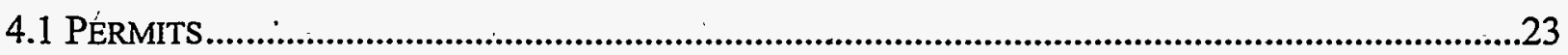

CHAPTER V - REFERENCES........................................................................................................................25 


\section{Chapter I - Purpose of and Need for Action}

\subsection{Purpose and Need}

The Bonneville Power Administration (BPA) operates and maintains one of the largest and most reliable electric transmission systems in the United States. BPA provides electricity throughout the Pacific Northwest using a large network of transmission lines, substations, and control centers. BPA uses a communication system that provides instant (or "real-time") information to operate and control this network.

The communication system is essential to operating the transmission network. The system identifies transmission lines that are in service, monitors the amount of electricity they are carrying, and tracks alarms and circuit breaker status. The system also detects faulty high voltage equipment and provides voice communications for maintenance, safety, and dispatch uses.

Because most of the equipment in BPA's existing communication system consists of 1960s-era microwave radio technology, BPA started a system-wide upgrade from microwave to fiber optics. The upgrade is needed to improve transmission system reliability and accommodate future growth.

Because BPA's 500-kV transmission lines are the backbone of the electric transmission network, BPA wants to integrate all of the main $500-\mathrm{kV}$ substations into the upgraded communications network. The Grizzly Substation is one of these main substations. BPA needs to add the Grizzly Substation to the fiber optic communications network to upgrade communications for electric power operations in central Oregon.

BPA's purposes, or objectives, in satisfying the need to add the Grizzly Substation to the fiber optic communications network include:

1. meeting BPA's safety, operations, maintenance, and reliability criteria for the transmission system; and, .

2. ensuring consistency with BPA's Business Plan Record of Decision to "fully participate in the competitive market for power, transmission, and energy services, and use success in the market to ensure the financial strength necessary to fulfill its mandates." while,

3. avoiding or minimizing adverse environmental effects; and,

4.' ensuring consistency with the Crooked River National Grassland Land and Resource Management Plan (Grassland Plan) (USFS August 1989).

\subsection{Agency Decisions}

BPA has applied for an easement on the Crooked River National Grassland (Grassland) for the project. The Grassland District Ranger will determine if the project is consistent with the Grassland Plan and decide whether to grant the easement and .

Environmental Assessment

Grizzly Substation Fiber Optic Project
Chapter 1

Purpose of and Need for Action 
authorize BPA to construct, operate, and maintain a communication transmission line. If an easement is granted, BPA will decide whether to construct the project.

Fiber optic cable installed on BPA's system may initially include capacity that is excess to BPA's current communications needs. This excess is intentional and allows BPA to meet peak demands and accommodate future growth. If the project is approved, BPA may market the excess fibers to another utility or telecommunications company. If BPA successfully markets the excess fibers, then BPA would execute a leasing contract with commercial entities. A commercial contract would provide revenues that could help BPA recover its costs and maintain competitive rates.

\subsection{Public Involvement/lssue Development}

A public scoping letter was mailed to interested individuals, organizations, business, government agencies, and tribes on October 9, 1997. One comment was received in response to the public scoping letter. This project will also be listed in the Winter 199798 Schedule of Proposed Actions for the Ochoco National Forest.

The Forest Service interdisciplinary team considered the response to help them identify any key issues. No key issues were identified, but the Forest Service interdisciplinary team was concerned about visual impacts along the new easement. Because of the visual concern, an Underground Installation Alternative that would bury the fiber optic cable along the new easement was developed. Other issues were identified and determined not to be key issues. The effects of the alternatives on these issues are discussed in Chapter III. 


\section{Chapter II - Alternatives Including the Proposed Action}

\subsection{Proposed Action}

\subsubsection{Project Location}

The Grassland proposes to grant an easement and authorize BPA to construct, operate, and maintain a fiber optic communications transmission line. The fiber optic project would be approximately $40 \mathrm{~km}$ ( 25 mile) long and would be located in Jefferson County, Oregon beginning about $18 \mathrm{~km}$ (11 miles) northeast and ending about $19 \mathrm{~km}$ (12 miles) south of Madras, Oregon. The project area is primarily contained with the boundaries of the Grassland, except for approximately $8 \mathrm{~km}$ (5 miles) that are on privately owned lands.

\subsubsection{Proposed Development}

The hardware used for this project would be as follows:

1. Cable. The cable for this project would be all dielectric self supporting (ADSS) containing 72 fibers in an outer protective sheath of black plastic. ADSS is a light-weight cable about $1.6 \mathrm{~cm}(5 / 8$ inch) in diameter.

2. Connector brackets. These special metal fittings would be installed on the wood poles or steel towers. The fiber optic cable would be attached to the pole or tower using the new fitting.

3. Wood poles. The wood poles would be approximately 17 meters (55 feet) high and placed in augured holes approximately 2.4 meters ( 8 feet) deep and 0.6 meters ( 2 feet) in diameter.

4. Splice boxes. Splice boxes are small metal cylinders that are attached to the poles or towers where the ends of two reel lengths of cable come together. The fibers are fused together to form a continuous connection and are contained in the splice box. Splice boxes are generally needed every 4 to $6 \mathrm{~km}$ ( 3 to 4 miles).

5. Vaults. Vaults are $4 \mathrm{ft}$. $\times 4 \mathrm{ft}$. $\times 4 \mathrm{ft}$. fiberglass or concrete boxes containing splice reels that are located on or below grade near the base of a pole or transmission tower. At vault locations, the cable would be routed in a 3" PVC conduit down the pole or tower and then run underground into the vault. Vaults are located where the commercially leased fibers break off from the BPA fiber.

6. Telecommunications equipment. This equipment includes the transmitters and receivers. The transmitters convert audio, video, or computer-generated messages into a series of light pulses that are transmitted through a fiberglass strand. The receivers convert the optical signals back to the original medium of communication. The telecommunications equipment is about the size of a home stereo system and would be installed on racks in the Grizzly Substation control house in the substation yard. 
The proposed project would consist of the three following segments:

1. Segment A: Approximately $6 \mathrm{~km}$ (4 miles) in length on BPA's Celilo - Sylmar line. This segment would begin near the intersection of the Celilo - Sylmar and Big Eddy - Redmond No. 1 transmission lines and end where the Celilo Sylmar line meets the John Day - Grizzly.No. 1 transmission line. Because the transmission towers on the Celilo - Sylmar line can not accommodate the addition of the fiber optic cable, approximately 16 wood poles would be placed adjacent to the existing transmission towers within the right-of-way. Connector brackets would be installed on each wood pole and fiber optic cable would be attached. A vault would be placed on the right-of-way at the beginning of this segment.

2. Segment B. Approximately $26 \mathrm{~km}$ (16: miles) in length beginning where the Celilo - Sylmar line meets the John Day - Grizzly No. 1 transmission line and ending at the Grizzly Substation. Connector brackets would be installed on the existing structures and fiber optic cable would be attached. Splice boxes would be installed on structures about every 4 to $6 \mathrm{~km}$ ( 3 to 4 miles) and a vault would be placed at the Grizzly Substation. From the vault, the BPA fiber would be routed into the existing substation control house.

3. Segment C. Approximately $8 \mathrm{~km}$ ( 5 miles) in length beginning at the Grizzly Substation and ending near structure 83/1 of BPA's Big Eddy - Redmond \#1 transmission line. BPA would acquire a new 15 meter.(50 foot) wide easement along existing county roads. Approximately 27 wood poles spaced about 275 meters (900 feet) apart would be placed within the new easement. Connector brackets would be installed on the poles, and fiber optic cable would be attached. A vault would be located near the intersection with Highway 26 and a splice box would be installed at the end of this segment.

\section{The proposed project location and segments are shown in Figure 2. 1.}

Existing access roads would be used on Segments A and B. In Segment C, no new road construction would occur. However, construction vehicles would drive on the natural terrain within the new easement to place the poles, attach hardware, and string the fiber optic cable. After construction, maintenance vehicles may occasionally drive along the natural terrain to access facilities needing repair. Also, vegetation may be periodically cleared to maintain access to facilities and prevent interference with the line.

At each splice site, including vault locations, a tensioning and pulling machine would be brought on to the easement. This machine is usually located on the back of a flatbed truck or a small trailer-mounted unit. Typically, a truck holds the reel at one end of the cable and a tensioner pulls the sock line, followed by the fiber optic cable, to the other end. 
The cable installation is generally accomplished in several steps. First, a construction person would drive to each tower along Segments $A$ and $B$ and attach the connector brackets. On Segment $C$, poles would be placed with the connector brackets attached. Next, a traveler, or pulley, to hold the sock line would be temporarily attached to the towers or poles. The sock line is a small cable that guides the fiber optic cable through the travelers and pulls the cable through the length of the transmission line. The sock line is generally driven along the right-of-way from tower to tower, although sometimes a helicopter is used. Finally, the fiber optic cable is inserted into and pulled through the. sock line, properly tensioned, and fused to the next reel. The sock line is then reeled in for use in the next section.

The amount of time workers would spend at each tower would be brief, as cable installation usually proceeds at a rate of $11-16$ kilometers ( $7-10$ miles) per week. This includes time required to attach hardware to each tower, flying or attaching the cable, and splicing the ends of the cable at splice sites.

The Grizzly Substation yard would be used to store the equipment and construction materials.

\subsection{Underground Installation Alternative}

This Alternative is the same as the Proposed Action, except that the fiber optic cable on Segment $C$ would be installed underground. This alternative addresses the concern about visual impacts along this segment. The fiber optic cable would be buried in a. trench with a minimum depth and width of approximately 0.9 meters ( 3 feet) The trench would be dug using a cable plow or trencher. The fiber optic cable would not be buried where Segment $C$ crosses a major natural gas pipeline or State Highway 26 . Wood poles would be erected so the fiber optic cable would span the pipeline and highway. A back hoe or trencher would reopen the trench to repair buried lines as needed.

\subsection{No Action}

Under this alternative, the Grassland District Ranger would not grant the new easement and BPA would not add the Grizzly Substation to the fiber optic network.

\subsection{Mitigation Included In Action Alternatives}

The following measures to reduce or avoid adverse impacts would be included as part of the Proposed Action or Underground Installation Alternative:

1. Avoid construction activities when the soil is saturated to reduce erosion potential and loss of soil productivity.

2. Where practicable, place poles outside of range allotment boundaries to avoid impacts to range lands from vehicle access. 
3. If poles are placed within the range allotment boundaries, install metal gates, where appropriate to allow for vehicle access.

4. Use certified weed free seed to revegetate disturbed areas with native plant species (or other suitable species) as soon as practicable to reduce introduction of weeds.

5. Clean vehicles when moving to new areas to control the spread of noxious weeds.

6. Monitor for new weed infestations for 4 years after project completion.

7. Locate utility poles at least 50 feet away from a burrowing owl nest site.

8. Minimize site clearing to reduce dust generation.

9. Use dust abatement measures to eliminate excessive dust problems.

\subsection{Alternatives Considered but Eliminated from Detailed Study}

\subsubsection{Using Existing Transmission Lines}

Oregon Electric Coop (Oregon Electric) has a distribution line that runs along a portion of Segment $C$. Using the poles on this line instead of acquiring new easement is not feasible because they would not meet BPA's reliability and safety criteria.

Reliability criteria include such things as ice loading factors, weight limitations, conductor configurations, and position or voltage limitations. The poles are not structurally capable of providing the strength needed to meet BPA's reliability criteria. Also, safety issues could result if BPA needed to perform emergency repairs on the fiber optic cable. Not owning the transmission line would limit BPA maintenance crews ability to verify or control a line outage during repair. The necessary coordination effort could cause significant maintenance delays and safety issues for BPA maintenance crews.

This alternative was eliminated from detailed study because it would not meet BPA's safety and reliability criteria: 


\subsection{Comparison of Alternatives}

Table 1 provides a summary of the ability of the three alternatives for this project to meet the project objectives. The decision factors are the purposes outlined in Section 1.1 of this EA.

Table 3 in Chapter III summarizes and compares the environmental consequences to the selected issues for each alternative.

Table 1 Predicted Performance Summary

\begin{tabular}{|c|c|c|c|}
\hline Decision Factors & Proposed Action & $\begin{array}{l}\text { Underground } \\
\text { Alternative }\end{array}$ & No Action ${ }^{1}$ \\
\hline $\begin{array}{l}\text { Consistent with the Crooked } \\
\text { River National Grassland Land } \\
\text { and Resource Management } \\
\text { Plan }\end{array}$ & No conflict & No conflict & No conflict \\
\hline $\begin{array}{l}\text { Avoids or minimizes possible } \\
\text { adverse environmental effects }\end{array}$ & No adverse impacts & No adverse impacts & No impacts \\
\hline $\begin{array}{l}\text { Consistent with BPA's } \\
\text { Business Plan Record of } \\
\text { Decision to "fully participate in } \\
\text { the competitive market for } \\
\text { power, transmission, and } \\
\text { energy services, and use } \\
\text { success in the market to } \\
\text { ensure the financial strength } \\
\text { necessary to fulfill its } \\
\text { mandates," }\end{array}$ & $\begin{array}{l}\text { Achieves BPA's } \\
\text { need in most cost } \\
\text { effective manner. } \\
\text {. }\end{array}$ & $\begin{array}{l}\text { Achieves BPA's } \\
\text { need in more costly } \\
\text { manner. }\end{array}$ & $\begin{array}{c}\text { Does not achieve } \\
\text { BPA's need. }\end{array}$ \\
\hline $\begin{array}{l}\text { Meets BPA's safety, } \\
\text { operations, maintenance, and } \\
\text { reliability criteria for the } \\
\text { transmission system }\end{array}$ & Meets all criteria. & Meets all criteria. & $\begin{array}{l}\text { Does not meet } \\
\text { operations and } \\
\text { reliability criteria. }\end{array}$ \\
\hline
\end{tabular}

${ }^{1}$ Under the No Action Alternative, BPA would continue to use the existing communications system. However, because most of BPA's central Oregon electric power operations are connected to the Grizzly Substation, electric power operations in central Oregon could become unreliable if the Grizzly Substation is not integrated into the fiber optic network. Under certain conditions, the unreliability could cause a telecommunications interruption or system failure. A system failure could result in damage to power circuit breakers or other equipment, costing hundreds of thousands of dollars. BPA could lose revenues while the damaged equipment is repaired or replaced and the transmission line is out of service. 


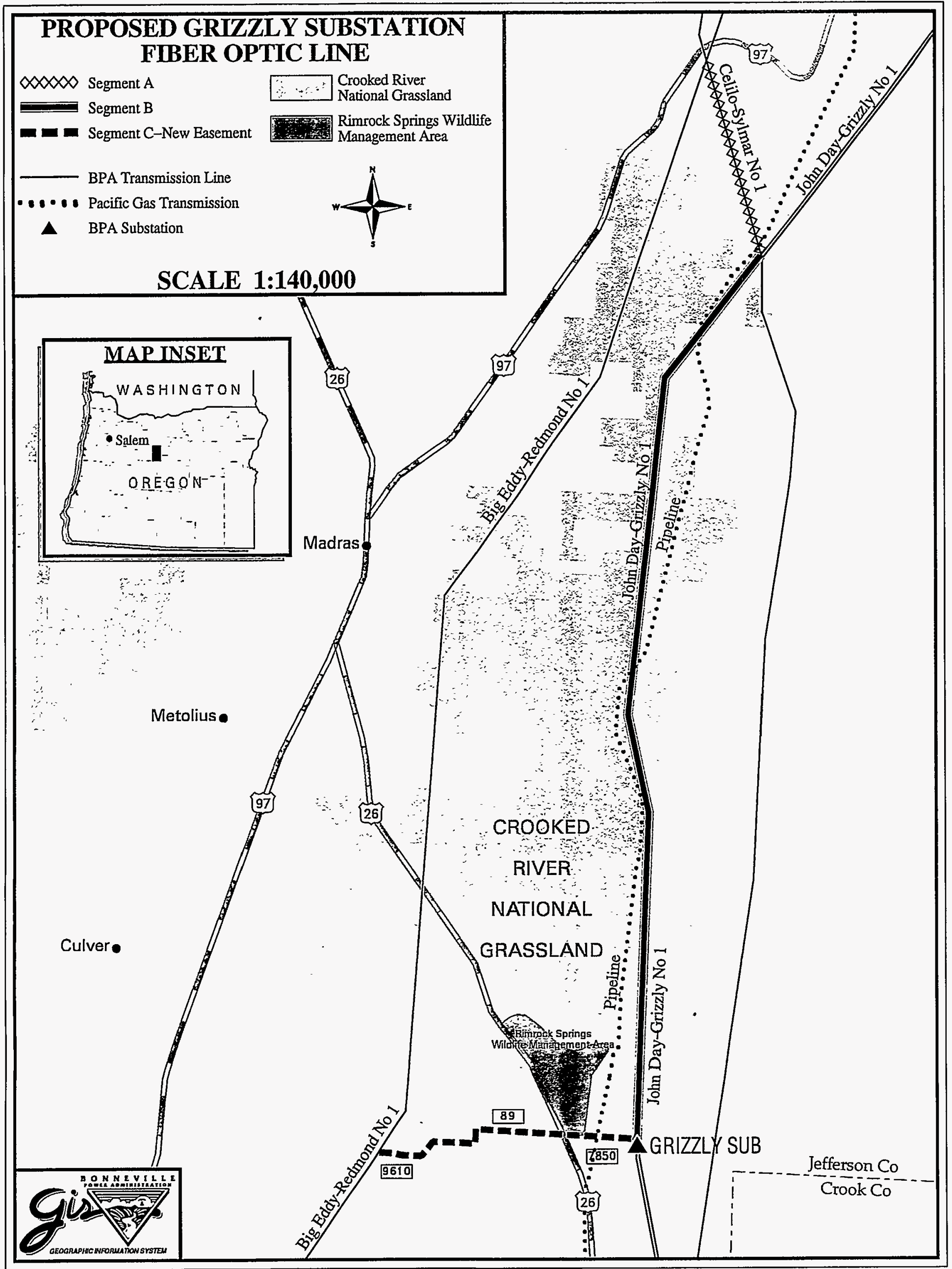




\section{Chapter III - Affected Environment, Environmental. Consequences, and Mitigation Measures}

\subsection{Geology and Soils}

\subsubsection{Affected Environment}

The project area is located in the Deschutes-Columbia Plateau and is predominated by volcanic formations. The Plateau covers approximately 63,000 square miles of Oregon, Washington, and Idaho. More specifically, the project area lies within the Deschutes Basin which extends from Wasco County to the north, to Powell Buttes in the south; and from the Green Ridge fault and Black Butte mountain in the west, to the towns of Madras and Gateway in the east (Orr, et. al, 1992).

The Deschutes-Columbia Plateau formed from enormous basalt flows that were covered by falling ash and lavas expelled from Cascadian volcanoes. The underlying basalt also has been overlain by sedimentation from historic floods and wind deposited loess. The Deschutes River, and other major rivers of this area (Metolius, Crooked River, etc.), has cut dramatic canyons through the basalt. These canyons are marked by steep walls of yellowish-brown sands and black basalts (Orr, et al, 1992).

Soils within the project area are primarily loams derived from basaltic parent material. Basalt cobbles of varying sizes are present at the surface in several areas. Slopes are gentle, ranging from $0 \%$ to approximately $5 \%$.

\subsubsection{Environmental Consequences}

\subsubsection{Proposed Action}

The proposed project would not impact geologic features because no unique geologic features are present within the project area.

Some soil disturbance and compaction could result as construction vehicles travel on native surfaces, where new poles are placed, and at splice locations. On Segments A and B, construction vehicles would use existing access roads where soil disturbance and compaction has already occurred. On Segment C, some soil disturbance and compaction may result as vehicles travel along the natural grade and where holes are dug. This could increase the erosion potential and cause a loss in soil productivity. However, these impacts would be reduced because construction activities would be avoided when the soil is saturated. 


\subsubsection{Underground Installation Alternative}

As well as the impacts that would result from the Proposed Action, this alternative would cause additional soil disturbance because of the trenching and backfilling process on Segment C. Some physical properties of the soil, such as its density and permeability, may change when the trench is backfilled and compacted around the cable. This could divert the flow of shallow ground water around the backfill and increase the erosion potential. However, the moderately permeable soils in the project area are well suited for backfilling and the level slopes would discourage any major runoff or erosion problems.

\subsubsection{No Action Alternative}

No impacts to geology or soils would result from this alternative.

\subsection{Land Use \& Recreation}

In compliance with the National Forest Management Act, the NEPA, and the Forest and Rangeland Renewable Resources Planning Act, the USFS developed the Crooked River National Grassland Resource Management Plan (Management Plan) and created Management Area Standards and Guidelines. These Standards and Guidelines are designed to ensure that all resource areas are able to achieve planned goals, objectives, and desired future conditions (USFS, 1989).

The Management Plan requires that all proposed activities must be compatible with the management area in which they would occur. The activity must also be performed in compliance with the Standards and Guidelines established for the 17 resource types $^{2}$ managed within the Grassland management area.

\subsubsection{Affected Environment}

Existing land uses within the project area include utilities and transportation corridors, range allotments, and agriculture. A short portion of Segment B would run just south of the state-designated Rimrock Springs Wildlife Management Area. This 450-acre area includes, ponds, marshes, and a short loop trail that provides access to two wildlife viewing platforms. The old Grassland field headquarters and winter pastures for government horses are also included in the management area.

Segments $A$ and $B$ are within the Utility Corridor management area. The emphasis of the management area is to accommodate energy-transmission facilities. (USFS, 1989). Segment $C$ is within the Antelope Winter Range where the management emphasis is to optimize antelope winter range conditions.

2 The 17 managed resources consist of the key Grassland resources and include such things as air quality, cultural resources, minerals and energy, recreation, soil, and fsh and wildlife. 
Segment $C$ crosses through three range allotments: Boyce, Rush, and Grizzly. There are five pastures to the south of the route and four pastures to the north.

\subsubsection{Environmental Consequences}

\subsubsection{Proposed Action}

The project would not alter existing land uses in Segments $A$ and $B$ because the utility corridor is already in place. Using the existing Grizzly Substation yard as a staging area would cause no land use impacts.

In Segment $\mathrm{C}$, construction equipment could impact grazing area fencing. However, this is unlikely to happen because the level slopes allow vehicle access from the substation without damaging fencelines. Any damage to grazing area fencing that results from project construction would be repaired immediately. The small amount of vegetation that would be removed by the pole placement on Segment $C$ would not adversely reduce the forage available for antelope or other grazing animals. The construction period on Segment $\mathrm{C}$ would be short and potential disruptions to grazing would be minimal. Once constructed, there would be no conflicts with existing land uses. Also, avoiding pole placement within the range allotments would minimize range land impacts from vehicle access.

No direct impacts on the quality or quantity of recreational opportunities would occur. Impacts on dispersed recreational activities such as hiking and hunting opportunities would be limited to visual and noise impacts occurring during construction. Any impacts would be temporary and localized.

Upon project completion, operational and maintenance activities would have minimal to no adverse effect on adjacent land uses, due to the current on-going maintenance activities in these areas. The fiber optic cable would be patrolled as part of BPA's regular transmission maintenance program. The maintenance program involves helicopter reconnaissance of the rights-of-way up to four times per year. BPA ground crews also patrol all rights-of-way at least once a year.

\subsubsection{Underground Installation Alternative}

Impacts from this alternative would be the same as with the Proposed Action, except potential disruptions to grazing during construction and/or maintenance along Segment $C$ would be of longer duration.

\subsubsection{No Action Alternative}

No impacts to land use and recreation would result from this alternative.

Environmental Assessment

Grizzly Substation Fiber Optic Project
Chapter 3

Affected Environment, Environmental Consequences, \& Mitigation Measures 


\subsection{Botanical Resources}

\subsubsection{Affected Environment}

The project area has been heavily disturbed by previous activities. Existing plant communities are dominated by cheatgrass, spring draba, and rabbitbrush. Also present in the project area are non-native crested wheatgrass fields as well as native bunchgrasses. Western juniper is the only tree species in the project area, some reaching heights of approximately 30 feet. Junipers greater than 20 feet have been removed on Segments $A$ and $B$ so they would not interfere with the electrical transmission lines.

Some isolated patches of Diffuse and Spotted Knapweed exist along Segment C. In the spring of 1998, Jefferson County plans to spot spray to control the knapweed in this area.

\subsubsection{Environmental Consequences}

\subsubsection{Proposed Action}

Juniper trees on Segment $C$ that would interfere with the fiber optic cable would be removed prior or during construction. However, the line would be placed to avoid tree removal where practicable. Also, vegetation interfering with the transmission lines would be removed during continuing maintenance activities.

Other impacts to vegetation would be limited to temporary ground cover and shrub understory species disturbances caused by vehicular traffic and pulling and tensioning equipment. Impacts would be low and short-term because existing access roads and/or rights-of-way would be used by ground vehicles to reach the tower sites, and rubber-tired ground based vehicles or helicopters would be used to string the cable. Areas where vegetation would be crushed or uprooted would be reseeded with a seed mixture appropriate for the area.

Disturbed areas could become infested with noxious weeds. These weeds take advantage of recently disturbed soils and lack of competing vegetation to invade recently disturbed areas. They can also be inadvertently spread when vehicles travel between infested and uninfested areas during maintenance. However, the mitigation measures specified in Section 2.4 would prevent or reduce the potential for noxious weed infestations.

\subsubsection{Underground Installation Alternative}

The impacts from this alternative would be the same as with the Proposed Action, except the impact area would be larger due to the continuous trench on Segment C.

Chapter 3

Affected Environment, Environmental Consequences, \& Mitigation Measures

Page 12
Environmental Assessment Grizzly Substation Fiber Optic Project 


\subsubsection{No Action Alternative}

No impacts to botanical resources would result from this alternative.

\subsection{Wildlife (including Fisheries)}

\subsubsection{Affected Environment}

Wildlife species thought to be present in the general project area include a variety of small mammals, reptiles, birds, deer, and antelope. The juniper trees and sagebrush understory throughout the general area provide nesting, foraging, and perching opportunities for birds. The trees also provide cover for small mammals and deer.

Raptors present in the general project area-include prairie falcons (Falco mexicanus) and red-tailed hawks (Buteo jamaicensis). No known nesting sites are present and no nesting habitat has been identified within the project area. Suitable nesting habitat for raptors exists over $21 \mathrm{~km}$ ( 13 miles) away along the canyon rims of Lake Billy Chinook and Lake Simtustus. The project area could provide marginal foraging habitat for these raptors.

A burrowing owl nest is located near Segment C, approximately 10 feet north of the intersection of road 7110 and 020 (T12S.R14 E NWSW 32).

Fish habitat exists in the watershed where the project would be located. However, only ephemeral swales located well upstream of any occupied habitat would be crossed by the project.

\subsubsection{Environmental Consequences}

\subsubsection{Proposed Action}

Installing the fiber optic cable and new poles could temporarily disturb wildlife within the right-of-way and adjacent wildlife habitat areas. Generally, any effects from this disturbance would be minor because of the temporary nature of the construction activities. Some direct mortality of wildlife inhabiting the right-of-way could result from equipment operations during project construction. However, few individual animals would likely be present on the existing access roads, along the county roads, or at the splice sites.

Raptor foraging on the project site may be temporarily interrupted during construction and maintenance periods. However, similar foraging opportunities are plentiful in the surrounding area and impacts are anticipated to be minimal. Because the project would be located either on previously developed facilities or along an existing county road, the loss of foraging habitat would be minimal.

Environmental Assessment

Grizzly Substation Fiber Optic Project
Chapter 3

Affected Environment, Environmental Consequences, \&

Mitigation Measures

Page 13 
The new fiber optic cable would slightly increase the risk of raptor collisions. However, no data is available to indicate that raptor collisions have been problematic with existing utility lines in the general area.

Disturbance to the burrowing owl nest would be avoided because utility poles would not be placed within 50 feet of the nest site.

No impacts to fisheries would occur.

\subsubsection{Underground Installation Alternative}

Impacts would be the same as with the Proposed Action, except the habitat disturbance area would be slightly greater and the duration of the construction activities would be longer.

\subsubsection{No Action Alternative}

No impacts to wildlife or fisheries resources would result from this alternative.

\subsection{Proposed, Endangered, Threatened, and Sensitive Species}

The Forest Management Act requires that the Forest Service maintain viable populations of all endemic species and desired non native species. The fish, wildlife, and plant species identified as sensitive by the Regional Forester are listed in Forest. Service Manual 2670 . Forest Service resource specialists prepared a project biological evaluation of these sensitive species.

\subsubsection{Affected Environment}

Forest Service sensitive species included in the biological evaluation are listed in Table 2. The northern bald eagle is also listed as threatened under the Endangered Species Act.

Table 2 Sensitive Species List

\begin{tabular}{|l|l|}
\hline Category & $\begin{array}{l}\text { Status of Species/Habitat on Project } \\
\text { Site }\end{array}$ \\
\hline \hline Wildlife: & Not present \\
1. California Big Horn Sheep & Potentially present \\
2. Northern Bald Eagle & Not present. \\
3. Western Sage Grouse & Not present. \\
4. Greater Sandhill Crane & Potentially present \\
6. Upland Sandpiper & Potentially present \\
7. Preble's Shrew & Not present. \\
8. California Wolverine & No impact. \\
9. Townsend's Big Eared Bat & Potentially present \\
\hline
\end{tabular}




\begin{tabular}{|l|l|}
\hline Fish: & No impact \\
1. Bull Trout & No impact \\
2. Redband Trout & Not present \\
3. Malheur Mottled Sculpin & Not present \\
4. Mid-Columbia Steelhead & \\
\hline Plants: & Not present \\
1. Allium brandegei & Not present \\
2. Allium campunalatum & Not present \\
3. Artemisia ludoviciana & Not present \\
4. Astragalus diaphanus var. & \\
diurnus & No impact \\
6. Astragalus howellii var. howellii & No impact \\
7. Astragalus peckii & Not present \\
8. Botrychium ascendens & Not present \\
9. Botrychium crenulatum & Not present \\
10. Botrychium lanceolatum & Not present \\
11. Botrychium minganense & Not present \\
12. Botrychium montanum & Not present \\
13. Calochortus longeburbatus var. & Not present \\
peckii & \\
14. Lycopodium complanatum & Not present \\
15. Mimulus washingtonensis & Not present \\
16. Oryzopsis hendersonii & Not present \\
17. Rorippa columbiae & Not present \\
18. Thelypodum eucosmum & Not present \\
19. Thelypodium howellii ssp & Not present \\
howellii & \\
\hline
\end{tabular}

No sitings of the northern bald eagle, long-billed curlew, upland sandpiper or California wolverine are recorded on or near the project site.

Resident and seasonally migratory bald eagles are present near Lake Billy Chinook, more than $21 \mathrm{~km}$ (13 miles) west of the project area, and its tributaries. Haystack Reservoir, approximately $2 \mathrm{~km}$ ( 1 mile) west of the project area, is a foraging site for some of the Lake Billy Chinook nesting and wintering bald eagles. A bald eagle nest exists approximately 5 miles south east of the project area. While bald eagles have not been observed on or near the project area, it could be marginally used by foraging eagles.

The 1997 Oregon Natural Heritage database indicates that no federally or state protected plants, animals, or their habitats are known to exist within 1/4-mile of . 
the project site. Pygmy rabbits, a federal species of concern, are present slightly more than 1/2-mile east of the John Day - Grizzly No. 1 line.

\subsubsection{Environmental Consequences}

\subsubsection{Proposed Action}

Bald eagles are the only protected species that could be potentially impacted by the project. Construction and maintenance activities may slightly disrupt foraging, remove a small amount of marginal foraging habitat, and slightly increase collision risk. Also, a slightly beneficial impact may result if the new poles are used for perching. None of the impacts would have an adverse effect on bald eagles.

No impacts to pygmy rabbits would occur because of their distance from the project area.

\subsubsection{Underground Installation Alternative}

Impacts would be the same as with the Proposed Action, except the habitat disturbance area would be greater, the duration of the construction activities would be slightly longer, collision risk would be less, and additional perching opportunities would be less.

\subsubsection{No Action Alternative}

No impacts to threatened or endangered plants, animals, or their habitats would result from this alternative.

\subsection{Wetlands and Floodplains}

\subsubsection{Affected Environment}

According to State of Oregon Flood Insurance Rate Maps, most of the project area is located outside any 500 year floodplains. A small section of Segment C, just east of the junction with Highway 26 , spans an intermittent stream that is designated as a special flood hazard area inundated by 100 year floods.

Some intermittent streams with vegetated streambeds cross Segments A and B. These dry washes are likely to flow only during extremely wet periods. Segment $B$ also spans Willow Creek near tower $88 / 1$ and Old Maids Creek near tower 73/6. None of the intermittent streams meet the jurisdictional wetland criteria defined in the US Army Corps of Engineers (COE) 1987 Jurisdictional Wetland Delineation Manual (COE, 1987). 


\subsubsection{Environmental Consequences}

\subsubsection{Proposed Action}

No impacts to floodplains or wetlands would result from the project. The existing structures on Segments $A$ and $B$ are located in uplands and existing roads would be used to access the tower sites. Staging areas and splice boxes would be located outside of any wetlands. Erosion control measures would be used to eliminate indirect wetland impacts that could result from vehicular disturbance, stormwater runoff, and sedimentation. The wetland on Segment $C$ near Highway 26 would be spanned by the cable and the vault box would be located outside of the wetland boundaries.

\subsubsection{Underground Installation Alternative}

Impacts would be the same as with the Proposed Action.

\subsubsection{No Action Alternative}

No impacts to wetlands or floodplains would result from this alternative.

\subsection{Historical and Cultural Resources}

\subsubsection{Affected Environment}

A Class I Literature Review was conducted by BPA and the Ochoco Forest Archaeologist. The archaeological records indicate that one known archaeological site is located on Segment $\mathrm{C}$. This site is the remains of a homestead. All that remains at the site is the homestead well.

\subsubsection{Environmental Consequences}

\subsubsection{Proposed Action}

The Proposed Action would have no effect on historical and cultural resources. The only known site along the project area would be completely avoided by construction activities.

\subsubsection{Underground Installation Alternative}

This alternative would have no effect on historical and cultural resources. The trench would be located to avoid the homestead well.

\subsubsection{No Action Alternative}

No impacts to historical or cultural resources would result from this alternative.

Environmental Assessment

Grizzly Substation Fiber Optic Project
Chapter 3

Affected Environment, Environmental Consequences, \&

Mitigation Measures 


\subsection{Aesthetics}

\subsubsection{Affected Environment}

The general project area is characterized by open expanses and by the presence of transportation and utility corridors. The Grizzly Substation and associated transmission lines are visible from Highway 26.

\subsubsection{Environmental.Consequences}

\subsubsection{Proposed Action.}

Some short-term impacts would occur from construction activities and minor ground disturbance at the new pole sites and splicing locations.

In Segment $A$, where new poles would be installed to carry the cable, the new poles would be shorter and less obtrusive than the structures already present. In Segment $B$ the fiber optic cable would be attached to existing strúctures where the impact has already been imposed on the landscape. In Segments A and B, the fiber optic cable added to the existing transmission rights-of-way would be barely visible and virtually indistinguishable from the existing facilities.

The visual impacts in Segment $C$ would be slightly greater. The new poles and fiber optic cable would be visible from Highway 26 and Grizzly Road. However, these roads are not scenic highways or sensitive viewing points. The new easement would parallel existing roads and a utility corridor. The use of wood poles would make the line difficult to discern from a distance against the natural landscape.

\subsubsection{Underground Installation Alternative}

The visual impacts from this alternative would be the same as the Proposed Action, except in Segment C. The short-term impacts on Segment $C$ would be slightly greater during trenching. Once the disturbed ground is revegetated, the visual impacts would be less because poles would not be visible. However, the vault.box near Highway 26 and poles erected to span Highway 26 and the gas pipeline would be visible.

\subsubsection{No Action Alternative}

No visual impacts would result from this alternative.

\subsection{Health and Safety}

The Proposed Action is not expected to have any adverse effect on public health or safety. Fiber optic cable does not carry an electrical current; therefore, it would not produce an electric or magnetic field (EMF) that is usually associated 
with power lines. In addition, the Proposed Action would not produce any hazardous or toxic materials.

\subsection{Air Quality}

\subsubsection{Affected Environment}

Air quality throughout the project area generally ranges from good to excellent depending on the time of year. The area can sometimes have high levels of natural windborne particulates caused by the combination of high wind conditions and large areas of fallow cropland. Burning crop and forest residues are often the source of airborne particulates during the summer and fall.

\subsubsection{Environmental Consequences}

\subsubsection{Proposed Action}

Site disturbance during construction activities could result in periódic, short-term localized increases in particulate emissions (dust). Emission primarily associated with vehicle exhaust from construction equipment and vehicles would be carbon monoxide, nitrogen oxides, sulfur oxides, and particulate matter. These impacts would be greatest on Segments $A$ and $C$ because the new pole installations would require an increased level of activity. Overall, only slight impacts to air quality are expected as a result of the Proposed Action. The impacts would be short-term and would not exceed any air quality standards. In addition, the mitigation measures included in Section 2.4 would minimize any air quality impacts.

\subsubsection{Underground Installation Alternative}

Air quality impacts for this alternative would be slightly greater than those for the Proposed Action because the trenching would cause more site disturbance. However, the impacts would be short-term and would not exceed any air quality standards.

\subsubsection{No Action Alternative}

No air quality impacts would result from this alternative.

\subsection{Noise}

\subsubsection{Affected Environment}

Audible noise is usually measured in decibel $(\mathrm{dB})$ on what is called the "A Scale" (dBA). It models how the human ear perceives sound. Standard ambient noise levels for rural locations such as the project area, range from 40 to $50 \mathrm{dBA}$. Environmental noise limits applicable to this project are regulated by state and

Environmental Assessment

Grizzly Substation Fiber Optic Project
Chapter 3

Affected Environment, Environmental Consequences, \&

Mitigation Measures

Page 19 
Federal regulations. No residences or sensitive noise receptors are near the project area.

\subsubsection{Environmental Consequences}

Minor noise impacts would result from activities associated with installation of new poles and stringing cable on existing structures. These impacts would be minimal because of the rural character of the project area. Any construction-related noise would be short-term and would not result in any serious disturbances to residences.

\subsection{Global Warming}

Global warming and climatic change, an extremely complex subject, is not fully understood in the scientific community. Nevertheless, it has been a major concern to scientific institutions and groups around the world. Much attention has been given to production of "greenhouse gasses" in the industrialized nations. However, the relationship between these substances and global warming trends is uncertain and continues to be the subject of extensive research. Also, much depends on the ability to model the incredibly complex behavior of the global-atmosphere.

The United States has taken the approach that it is prudent to take some actions now to reduce some emissions and has promised to reduce its greenhouse gas emissions to 1990 levels by the year 2000. To accomplish this, the Clinton administration has issued the Climate Change Action Plan.

In regards to global warming, much attention has been paid to reducing the production of carbon dioxide $\left(\mathrm{CO}_{2}\right)$. The amounts of $\mathrm{CO}_{2}$ that would be contributed by the Proposed Action would be relatively minor and short-term and would not result in any significant global climate change.

Table 3 summarizes the affected environment, potential impacts, and available mitigation measures for the Proposed Action, the Underground Installation Alternative, and the No Action Alternative. 
Table 3 Summary of Potential Environmental Impacts and Mitigation

\begin{tabular}{|c|c|c|c|c|c|}
\hline \multirow[t]{2}{*}{ Resource } & \multirow{2}{*}{$\begin{array}{l}\text { Affected } \\
\text { Environment }\end{array}$} & \multicolumn{3}{|c|}{ Potential Impacts } & \multirow{2}{*}{$\begin{array}{l}\text { Mitigation } \\
\text { Measures }\end{array}$} \\
\hline & & Proposed Action & $\begin{array}{l}\text { Underground } \\
\text { Installation }\end{array}$ & No Action & \\
\hline Geology \& Soils & $\begin{array}{l}\text { Volcanic formations } \\
\text { dominate. Basalt } \\
\text { derived loam soils. }\end{array}$ & $\begin{array}{l}\text { No impacts to geological } \\
\text { formations. Some potential for } \\
\text { increased erosion \& loss of } \\
\text { soil productivity. }\end{array}$ & $\begin{array}{l}\text { Same as Proposed Action } \\
\text { except greater soil disturbance } \\
\text { from trenching. }\end{array}$ & No impacts. & $\begin{array}{l}\text { Avoid construction } \\
\text { \& maintenance } \\
\text { activities when soil } \\
\text { is saturated. }\end{array}$ \\
\hline $\begin{array}{l}\text { Land Use \& } \\
\text { Recreation }\end{array}$ & $\begin{array}{l}\text { Utilities, } \\
\text { transportation, range } \\
\text { allotments, antelope } \\
\text { winter range, and } \\
\text { agriculture. }\end{array}$ & $\begin{array}{l}\text { May damage grazing area } \\
\text { fencing. Minor reduction in } \\
\text { forage for grazing animals. } \\
\text { Minor grazing disruptions. No } \\
\text { impacts to recreation. }\end{array}$ & $\begin{array}{l}\text { Same as Proposed Action } \\
\text { except longer duration for } \\
\text { grazing disruptions. }\end{array}$ & No impacts. & $\begin{array}{l}\text { Where practicable, } \\
\text { place poles outside } \\
\text { of range allotment } \\
\text { boundaries to } \\
\text { avoid impacts to } \\
\text { range lands from } \\
\text { vehicle access. If } \\
\text { poles on Segment } \\
\mathrm{C} \text { are placed within } \\
\text { the allotment } \\
\text { boundaries, install } \\
\text { metal gates where } \\
\text { appropriate. }\end{array}$ \\
\hline Botanical & $\begin{array}{l}\text { Western juniper/big } \\
\text { sagebrush/bluebunch } \\
\text { wheatgrass scrub } \\
\text { vegetation. }\end{array}$ & $\begin{array}{l}\text { Removal of some juniper trees } \\
\text { on Segment C. Some } \\
\text { vegetation disturbance. } \\
\text { Disturbed areas could become } \\
\text { infested with noxious weeds. }\end{array}$ & $\begin{array}{l}\text { Same as Proposed Action } \\
\text { except greater vegetation } \\
\text { disturbance on Segment C. }\end{array}$ & No impacts. & $\begin{array}{l}\text { - Revegetate } \\
\text { disturbed areas } \\
\text { with native plant } \\
\text { species. } \\
\text { - Use standard } \\
\text { weed control } \\
\text { practices. } \\
\text { - Monitor for weed } \\
\text { infestations. }\end{array}$ \\
\hline Wildlife & $\begin{array}{l}\text { Small mammals, } \\
\text { reptiles, birds, deer } \\
\text { and antelope, } \\
\text { Burrowing owl nest. }\end{array}$ & $\begin{array}{l}\text { Temporary disturbance to } \\
\text { wildlife and foraging raptors. } \\
\text { Slight increase in raptor } \\
\text { collision risk. }\end{array}$ & $\begin{array}{l}\text { Same as Proposed Adtion } \\
\text { except has slightly greater } \\
\text { habitat disturbance and less } \\
\text { collision risk. }\end{array}$ & No impacts. & $\begin{array}{l}\text { Do not place utility } \\
\text { pole within } 50 \text { feet } \\
\text { of burrowing owl } \\
\text { nest. }\end{array}$ \\
\hline
\end{tabular}

Environmental Assessment

Grizzly Substation Fiber Optic Project
Chapter 3

Affected Environment, Environmental Consequences, \&

Mitigation Measures

Page 21 


\begin{tabular}{|c|c|c|c|c|c|}
\hline \multirow[t]{2}{*}{ Resource } & \multirow{2}{*}{$\begin{array}{l}\text { Affected } \\
\text { Environment }\end{array}$} & \multicolumn{3}{|c|}{ Potential Impacts } & \multirow{2}{*}{$\begin{array}{l}\text { Mitigation } \\
\text { Measures }\end{array}$} \\
\hline & & Proposed Action & $\begin{array}{l}\text { Underground } \\
\text { Installation }\end{array}$ & No Action & \\
\hline $\begin{array}{l}\text { Proposed, } \\
\text { Threatened, } \\
\text { Endangered, or } \\
\text { Sensitive } \\
\text { Speces }\end{array}$ & Bald Eagles & $\begin{array}{l}\text { Slight disruption to foraging, } \\
\text { minor removal of marginal } \\
\text { foraging habitat, and slight } \\
\text { increase of collision risk. New } \\
\text { poles may provide perching } \\
\text { opportunities. }\end{array}$ & $\begin{array}{l}\text { Same as Proposed Action } \\
\text { except slighter greater } \\
\text { disturbance area, less collision } \\
\text { risk, longer duration of } \\
\text { foraging disruption, no } \\
\text { perching opportunities. }\end{array}$ & No impacts. & None. \\
\hline $\begin{array}{l}\text { Wetlands \& } \\
\text { Floodplains }\end{array}$ & $\begin{array}{l}\text { Small floodplain near } \\
\text { Hwy } 26 \text { \& Segment C' } \\
\text { junction. No } \\
\text { jurisdictional wetlands: }\end{array}$ & No impacts. & No impacts. & No impacts. & None. \\
\hline $\begin{array}{l}\text { Historical \& } \\
\text { Cultural - }\end{array}$ & $\begin{array}{l}\text { Homestead well on } \\
\text { Segment C. }\end{array}$ & No impacts. & No impacts. & No impacts. & None. \\
\hline Aesthetics & $\begin{array}{l}\text { Open expanses, utility } \\
\text { \& transportation } \\
\text { corridors. }\end{array}$ & $\begin{array}{l}\text { Short term impacts from } \\
\text { construction activities \& } \\
\text { ground disturbance.' New } \\
\text { poles difficult to discern on } \\
\text { Segment C. }\end{array}$ & $\begin{array}{l}\text { Same as Proposed Action in } \\
\text { Segments A \& B. Less } \\
\text { impacts on Segment C once } \\
\text { trench is revegetated. }\end{array}$ & No impacts. & None. \\
\hline Health \& Safety & $\begin{array}{l}\text { No EMF, hazardous or } \\
\text { toxic materials. }\end{array}$ & No impacts. & No. impacts. & No impacts. & None. \\
\hline Air Quality & $\begin{array}{l}\text { Usually good to } \\
\text { excellent; some } \\
\text { particulates from } \\
\text { fallow croplands.\& } \\
\text { burning activities. }\end{array}$ & $\begin{array}{l}\text { Short-term localized increase } \\
\text { in dust emissions. No air } \\
\text { quality standards exceeded. } \\
\therefore\end{array}$ & $\begin{array}{l}\text { Slightly greater increase in } \\
\text { dust emission during trenching } \\
\text { on Segment C. No air quality } \\
\text { standards exceeded. }\end{array}$ & No impacts. & $\begin{array}{l}\text { - Minimize site } \\
\text { clearing. } \\
\text { - Use dust } \\
\text { abatement } \\
\text { measures as } \\
\text { needed. }\end{array}$ \\
\hline Noise & $\begin{array}{l}\text { No residential } \\
\text { receptors. }\end{array}$ & $\begin{array}{l}\text { Minor noise impacts during } \\
\text { construction activities. }\end{array}$ & Same as Proposed Action. & No impacts. & None. \\
\hline Global Warming & $\begin{array}{l}\text { international concern } \\
\text { about greenhouse gas } \\
\text { emissions. }\end{array}$ & $\begin{array}{l}\text { Very minor amounts of } \mathrm{CO}_{2} \\
\text { emissions not significant. }\end{array}$ & Same as Proposed Action. & No impacts. & None. \\
\hline
\end{tabular}

\section{Chapter 3}

Affected Environment, Environmental Consequences,

\& Mitigation Measures

Page 22
Environmental Assessment Grizzly Substation Fiber Optic Project 


\section{Chapter IV - Environmental Consultation, Review and Permit Requirements}

\subsection{Permits}

In accordance with NEPA guidelines and in support of the environmental assessment; a regulatory review was conducted to evaluate the environmental consultation, review and permit requirements for the construction of Grizzly Substation Fiber Optic Tap Line. A summary of the regulatory requirements for the Project are included in-Table 4.1.

Table 4.1 Regulatory Analysis of Proposed Grizzly Substation Fiber Optic Tap Line

\begin{tabular}{|c|c|}
\hline Applicable Regulations & Comments \\
\hline $\begin{array}{l}\text { National Environmental } \\
\text { Policy Act (NEPA) (CFR } 33 \\
\text { Part 230) }\end{array}$ & $\begin{array}{l}\text { This Environmental Assessment (EA) is prepared in accordance with } \\
\text { Forest Service and Department of Energy NEPA implementing } \\
\text { regulations. The US Forest Service and BPA will consider the } \\
\text { findings from this EA to make decisions on the Project. }\end{array}$ \\
\hline $\begin{array}{l}\text { Endangered Species Act } \\
\text { (CFR } 50 \text { Part 17/Part 402) }\end{array}$ & $\begin{array}{l}\text { The Biological Evaluation determined that no state or federally listed } \\
\text { threatened or endangered species or critical habitat would be affected } \\
\text { by the project. }\end{array}$ \\
\hline $\begin{array}{l}\text { State, Areawide, and Local } \\
\text { Plan and Program } \\
\text { Consistency }\end{array}$ & $\begin{array}{l}\text { In accordance with Executive Order } 12372 \text {, this.EA will be circulated } \\
\text { to the appropriate state agencies to satisfy review and consultation } \\
\text { requirements. In addition, the project has been coordinated through } \\
\text { the Crooked River National Grasslands. The project is consistent } \\
\text { with the Crooked River National Grasslands Management Plan. }\end{array}$ \\
\hline $\begin{array}{l}\text { National Historic Preservation } \\
\text { Act, The Native American } \\
\text { Graves Protection and } \\
\text { Repatriation Act, The } \\
\text { American Indian Religious } \\
\text { Freedom Act }\end{array}$ & $\begin{array}{l}\text { A Class III cultural resources survey found no resources in the project } \\
\text { area potentially eligible for the National Register of Historic Places. } \\
\text { No graves have been identified on the site. }\end{array}$ \\
\hline Floodplain Management & $\begin{array}{l}\text { Executive Order } 11988 \text { and Department of Energy regulations } \\
\text { implementating the Executive Order (10 CFR part 1022) direct BPA to } \\
\text { avoid, to the extent possible, the long- and short-term adverse } \\
\text { impacts associated with the occupancy and modification of } \\
\text { floodplains, and avoid direct and indirect support of floodplain } \\
\text { development wherever there is a practicable alternative. No } \\
\text { floodplains would be impacted by the project. }\end{array}$ \\
\hline Wetlands Protection & $\begin{array}{l}\text { Execute Order } 11990 \text { and Department of Energy regulations } \\
\text { implementing the Executive Order (10 CFR Part 1022) direct BPA to } \\
\text { minimize the destruction, loss, or degradation of wetlands; and to } \\
\text { preserve and enhance the natural and beneficial values of wetlands. } \\
\text { No wetlands would be impacted by the project.. }\end{array}$ \\
\hline Farmland Protection & $\begin{array}{l}\text { The Farmland Protection Policy Act (7 USC } 4201 \text { et seg.) requires } \\
\text { Federal agencies to identify and consider adverse effects of their } \\
\text { programs on the preservation of farmlands. No farmlands would be } \\
\text { impacted by the project.. }\end{array}$ \\
\hline $\begin{array}{l}\text { Permits for Rights-of-Way on } \\
\text { Public land }\end{array}$ & $\begin{array}{l}\text { This EA will be used by the Forest Service to decide whether to grant } \\
\text { an easement for the project to BPA. }\end{array}$ \\
\hline
\end{tabular}

Environmental Assessment

Grizzly Substation Fiber Optic Project
Chapter 5

Environmental Consultation, Review and Permit

Requirements 


\begin{tabular}{|c|c|}
\hline Non - Applicable Regulations & Comments \\
\hline $\begin{array}{l}\text { Fish and Wildlife Coordination Act (FWCA) } \\
\text { (16 USC } 2901 \text { et seq.) }\end{array}$ & $\begin{array}{l}\text { The FWCA requires Federal agencies to consult } \\
\text { with the U.S. Fish and Wildlife Service whenever } \\
\text { they plan to conduct, license, or permit an activity } \\
\text { involving the impoundment, diversion, deepening, } \\
\text { control, or modification of a stream or body of water. } \\
\text { These types of activities would not be conducted as } \\
\text { a part of the proposed project. }\end{array}$ \\
\hline $\begin{array}{l}\text { Pacific Northwest Electric Power Planning } \\
\text { and Conservation Act ( } 16 \text { USC } 839 \text { et seq.) }\end{array}$ & $\begin{array}{l}\text { This act contains provisions intended to protect, } \\
\text { mitigate, and enhance the fish and wildlife (including } \\
\text { their spawning grounds and habitat) of the Columbia } \\
\text { River and its tributaries. The proposed project does } \\
\text { not involve any activities that are directly applicable } \\
\text { to this act. }\end{array}$ \\
\hline $\begin{array}{l}\text { Migratory Bird Treaty Act (MBTA) } \\
\text { (16 U.S.C. 703-711) } \\
\text { (50 CFR Part 10, 50 CFR 21) } \\
\therefore\end{array}$ & $\begin{array}{l}\text { The MBTA makes it unlawful to take, possess, buy, } \\
\text { sell, purchase, or barter any migratory bird listed in } \\
50 \text { CFR Part 10, including feathers, or other parts, } \\
\text { nests, eggs, or products, except as allowed by } \\
\text { implementing regulations ( } 50 \text { CFR 21). The Project } \\
\text { would not intentionally take any MBTA listed birds. }\end{array}$ \\
\hline $\begin{array}{l}\text { Clean Water Act (CFR 40) and } \\
\text { (CFR } 33 \text { Part 330) CWA Section } 401 \\
\text { EPA Section } 404\end{array}$ & $\begin{array}{l}\text { Section } 404 \text { of the CWA regulates the discharge of } \\
\text { dredged or fill material into waters of the United } \\
\text { States. No permits are needed for this Project. }\end{array}$ \\
\hline Coastal Zone Management Consistency & $\begin{array}{l}\text { The Coastal Zone Management Act of } 1972 \text { requires } \\
\text { that Federal actions be consistent, to the maximum } \\
\text { extent practicable, with approved state Coastal Zone } \\
\text { management Projects. No coastal zones would be } \\
\text { impacted by this project. }\end{array}$ \\
\hline $\begin{array}{l}\text { Federal Insecticide Fungicide and } \\
\text { Rodenticide Act (FIFRA) (CFR 40) }\end{array}$ & $\begin{array}{l}\text { FIFRA regulates the handling, application and } \\
\text { disposal of pesticide products. The Project would } \\
\text { not utilize pesticide products. }\end{array}$ \\
\hline $\begin{array}{l}\text { Toxic Substance Control Act } \\
\text { (TSCA) (CFR 40) }\end{array}$ & $\begin{array}{l}\text { TSCA regulates the manufacture and use of toxic } \\
\text { chemicals. The Project would not manufacture or } \\
\text { use toxic substances, }\end{array}$ \\
\hline $\begin{array}{l}\text { Resource Conservation and Recovery Act } \\
\text { (RCRA) (CFR 40) }\end{array}$ & $\begin{array}{l}\text { RCRA regulates the storage, handling and disposal } \\
\text { of solid and hazardous wastes. The Project would } \\
\text { not handle, manifacture, store or dispose of } \\
\text { hazardous waste. }\end{array}$ \\
\hline $\begin{array}{l}\text { Safe Drinking Water Act (SDWA) } \\
\text { (CFR 40) }\end{array}$ & $\begin{array}{l}\text { SDWA regulates the protection of drinking water } \\
\text { aquifers. The Project would not impact a principle } \\
\text { or sole-source aquifer }\end{array}$ \\
\hline $\begin{array}{c}\text { Wild and Scenic Rivers (WSR) (CFR 23) } \\
\ddots\end{array}$ & $\begin{array}{l}\text { The Project would not impact a designated wild or } \\
\text { scenic river }\end{array}$ \\
\hline $\begin{array}{l}\text { Executive Order 11988, Floodplain } \\
\text { Management and DOE Guidelines (10 CFR } \\
\text { 1022) }\end{array}$ & $\begin{array}{l}\text { The Project would not adversely affect any } \\
\text { floodplains or wetlands. }\end{array}$ \\
\hline
\end{tabular}

Chapter 4

Environmental Consultation, Review and Permit Requirements

Page 24
Environmental Assessment Grizzly Substation Fiber Optic Project 